\title{
Korelasi Antar Sub Topik Dalam Pokok Bahasan Sifat Koligatif Larutan Pada Siswa Kelas XII-IPA SMA Negeri Palangka Raya Tahun Ajaran 2018/2019
}

\author{
Christiana Sinta \\ Program Studi Pendidikan Kimia, Fakultas Keguruan dan Ilmu Pendidikan , \\ Universitas Palangka Raya, Indonesia \\ JL. Yos Sudarso, Palangka, Jekan Raya, Kota Palangka Raya \\ Email: csinta10@gmail.com
}

Diterima: 10 Mei 2021; Disetujui: 28 Mei 2021; Diterbitkan: 09 Juni 2021

\begin{abstract}
ABSTRAK
Sifat koligatif larutan adalah sifat larutan yang hanya bergantung pada konsentrasi pertikel zat terlarutnya. Konsep sifat koligatif dalam silabus KTSP dan K2013 memuat urutan topik yang sama, yakni PTUL, KTDL, PTBL, dan TOL. Urutan sub topik tersebut perlu diteliti berdasarkan pemahaman siswa menggunakan metode korelasi berdasarkan nilai korelasi hasil tes kemampuan siswa kelas XII-IPA. Penelitian ini bertujuan untuk menjelaskan korelasi urutan sub topik dalam pokok bahasan sifat koligatif larutan pada siswa berdasarkan nilai koefisien korelasi, nilai rata-rata tes (mean) hasil tes kemampuan, dan jenis kelamin siswa pada kelas XII-IPA SMA Negeri Palangka Raya tahun ajaran 2018/2019. Data kemampuan siswa dijaring menggunakan Tes Kemampuan Sifat Koligatif Larutan (Tes KSKL). Data yang diperoleh kemudian dianalisis secara deskriptif. Hasil Penelitian menunjukkan urutan sub topik berdasarkan nilai korelasi adalah PTBL, KTDL, TOL, dan PTUL; berdasarkan rata-rata tes (mean) adalah KTDL, PTBL, TOL, dan PTUL; dan berdasarkan jenis kelamin pada siswa laki-laki adalah KTDL, PTBL, TOL, dan PTUL serta pada siswa perempuan adalah KTDL, PTBL, PTUL, dan TOL.
\end{abstract}

Kata kunci: sifat koligatif larutan, koefisien korelasi, mean, tingkat kesukaran, urutan penyajian materi.

\section{PENDAHULUAN}

Pengertian ilmu kimia menurut Depdiknas (2003) dan Irfan (2000) adalah cabang ilmu pengetahuan alam yang mengkhususkan diri di dalam mempelajari struktur materi, sifat-sifat materi, perubahan suatu materi menjadi materi lain, serta energi yang menyertai perubahan materi. Mata pelajaran kimia diklasifikasikan sebagai mata pelajaran yang cukup sulit bagi sebagian siswa SMA/MA (Kasmadi, 2010). Menurut Mulyasa (2006), mata pelajaran kimia di SMA/MA bertujuan agar siswa memiliki kemampuan memahami konsep, prinsip, hukum, dan teori kimia serta saling keterkaitan penerapannya untuk menyelesaikan masalah dalam kehidupan sehari-hari. Berdasarkan definisi dan ciri-ciri dari ilmu kimia tersebut, diketahui bahwa kajian dalam ilmu kimia merupakan konsep yang saling berhubungan, terarah, dan sistematis Menurut Norjana (2016) konsep di dalam ilmu kimia merupakan konsep yang berjenjang dari yang sederhana ke konsep yang lebih tinggi tingkatannya. 
Tingkatan konsep ilmu kimia dalam silabus kurikulum biasanya telah diatur oleh pakar untuk diurutkan sesuai dengan jenjang konsep ilmu, yaitu sederhana menuju kompleks yang mengakibatkan buku pembelajaran yang beredar untuk siswa sekolah juga memuat urutan materi pembelajaran yang sama. Konsep sifat koligatif larutan misalnya, dalam silabus KTSP dan K2013 memuat urutan sub topik yang dipelajari dalam konsep tersebut yaitu penurunan tekanan uap larutan, kenaikan titik didih larutan, penurunan titik beku larutan, dan tekanan osmotik larutan. Riset dilakukan pada beberapa buku yang digunakan untuk siswa Sekolah Menengah Atas dan mahasiswa. Pada buku Sudarmo (2018) dan Chang (2010) memuat urutan topik yang sama, yaitu sifat koligatif larutan yaitu penurunan tekanan uap larutan, kenaikan titik didih larutan, penurunan titik beku larutan, dan tekanan osmotik larutan.

Namun, urutan sub topik tersebut perlu diteliti berdasarkan pemahaman langsung siswa dalam mempelajari konsep sifat koligatif larutan dan mengerjakan soal tes. Sub topik yang disusun tersebut ditujukan untuk dipelajari oleh siswa bukan pakar dan memungkinkan urutan topik mengalami pergeseran urutan bila diuji kepada siswa. Cara yang dapat dilakukan untuk mengetahuinya yaitu dengan menggunakan metode korelasi. Penelitian korelasi dilakukan untuk mengetahui bagaimanakah urutan antar sub topik dalam pokok bahasan sifat koligatif larutan berdasarkan hubungan atau nilai korelasi hasil tes kemampuan siswa terutama di kelas XII-IPA. Korelasi antar sub topik dalam pokok bahasan sifat koligatif larutan dapat dihitung dengan menggunakan tes tertulis. Cara menentukan urutan sub topik dalam pokok bahasan sifat koligatif larutan, yakni dengan mengkorelasikan hasil tes kemampuan siswa dan membandingkan hasilnya dengan urutan materi pokok bahasan sifat koligatif larutan yang telah ditentukan oleh pakar dalam silabus.

Jika demikian, urutan sub topik dalam pokok bahasan sifat koligatif larutan bisa saja berbeda. Berdasarkan latar belakang masalah, maka dilakukan penelitian lebih lanjut dengan judul "Korelasi Antar Sub Topik dalam Pokok Bahasan Sifat Koligatif Larutan pada Siswa Kelas XII-IPA SMA Negeri Palangka Raya Tahun Ajaran 2018/2019".

\section{METODOLOGI PENELITIAN}

Penelitian ini merupakan penelitian deskriptif dengan menggunakan pendekatan kuantitatif. Penelitian ini bertujuan untuk menguji dan menjelaskan mengenai korelasi urutan sub topik terhadap hubungan antar variabel berdasarkan nilai korelasi hasil tes kemampuan dan nilai rata-rata tes (mean) terhadap sub topik dalam pokok bahasan Sifat Koligatif Larutan pada siswa kelas XII-IPA SMA Negeri Palangka Raya tahun ajaran 2018/2019, sehingga penelitian ini termasuk dalam jenis penelitian korelasional.

Penelitian ini dilaksanakan pada semester genap tahun ajaran 2018/2019. Pengambilan data pada penelitian melibatkan beberapa SMA Negeri di kota 
Palangka Raya. Subjek dalam penelitian ini adalah siswa kelas XII-IPA yang berjumlah 221 siswa.

Tabel 6. Waktu, Tempat, dan Jumlah Subjek dalam Pengambilan Data

\begin{tabular}{|c|c|c|c|c|}
\hline Nama Sekolah & $\begin{array}{l}\text { Kode } \\
\text { Sekolah }\end{array}$ & Kelas & $\begin{array}{c}\text { Jumlah Subjek } \\
\text { Penelitian }\end{array}$ & $\begin{array}{c}\text { Tanggal Pengambilan } \\
\text { Data }\end{array}$ \\
\hline \multirow[t]{2}{*}{ Raya } & SMA A & $\begin{array}{c}\text { XII-IPA } \\
2\end{array}$ & 40 & 21 Februari 2019 \\
\hline & & $\begin{array}{c}\text { XII-IPA } \\
3\end{array}$ & 40 & 27 Februari 2019 \\
\hline \multirow[t]{2}{*}{ Raya } & SMA B & $\begin{array}{c}\text { XII-IPA } \\
1\end{array}$ & 29 & 1 Maret 2019 \\
\hline & & $\begin{array}{c}\text { XII-IPA } \\
2 \\
\end{array}$ & 30 & 6 Maret 2019 \\
\hline \multirow[t]{3}{*}{ Raya } & SMA C & $\begin{array}{c}\text { XII-IPA } \\
3\end{array}$ & 40 & 5 Maret 2019 \\
\hline & & $\begin{array}{c}\text { XII-IPA } \\
4\end{array}$ & 42 & 7 Maret 2019 \\
\hline & Cotal & & 221 siswa & \\
\hline
\end{tabular}

Asumsi penelitian ini adalah siswa sudah pernah mendapatkan materi pelajaran sifat koligatif larutan, yakni Penurunan Tekanan Uap Larutan $(\Delta \mathrm{P})$, Kenaikan Titik Didih Larutan $\left(\Delta \mathrm{T}_{\mathrm{b}}\right)$, Penurunan Titik Beku Larutan $\left(\Delta \mathrm{T}_{\mathrm{f}}\right)$, dan Tekanan Osmotik Larutan $(\pi)$ pada kelas XII-IPA SMA semester ganjil tahun ajaran 2018/2019.

Instrumen yang digunakan dalam penelitian ini adalah tes kemampuan sifat koligatif larutan berupa tes objektif berbentuk soal pilihan ganda sebanyak 24 soal. Cakupan materi pada konsep sifat koligatif larutan yang tersebar pada indikator dalam Tes Kemampuan Sifat Koligatif Larutan (Tes KSKL) dengan pernyataan seperti pada Tabel 7 .

\section{Tabel 7. Indikator Tes Kemampuan Sifat Koligatif Larutan}

\begin{tabular}{|c|c|c|}
\hline $\begin{array}{l}\text { SUB BAB } \\
\text { (KONSEP) }\end{array}$ & INDIKATOR & $\begin{array}{c}\text { BUTIR } \\
\text { SOAL }\end{array}$ \\
\hline $\begin{array}{l}\text { Penurunan Tekanan } \\
\text { Uap Larutan }(\Delta \mathrm{P})\end{array}$ & $\begin{aligned} & \text { Menganalisis tekanan uap beberapa larutan } \\
& \text { nonelektrolit jika massa pelarut sama dan jumlah } \\
& \text { partikel zat terlarut berbeda. } \\
& \text { \& } \\
& \text { Menganalisis penurunan tekanan uap larutan jika } \\
& \text { ditambahkan zat elektrolit. } \\
& \text { \& } \\
& \text { Menentukan penurunan tekanan uap larutan } \\
& \text { nonelektrolit. } \\
& \text { \& Menentukan penurunan tekanan uap larutan elektrolit. } \\
& \text { \& Menentukan tekanan uap jenuh larutan nonelektrolit. } \\
& \text { \& } \text { Menentukan tekanan uap jenuh larutan elektrolit. }\end{aligned}$ & $\begin{array}{l}3 \\
4 \\
5 \\
6\end{array}$ \\
\hline $\begin{array}{l}\text { Kenaikan Titik Didih } \\
\text { Larutan }\left(\Delta \mathrm{T}_{\mathrm{b}}\right)\end{array}$ & $\begin{array}{l}\text { * Menganalisis titik didih larutan nonelektrolit jika } \\
\text { molalitas zat terlarut berbeda. }\end{array}$ & 7 \\
\hline
\end{tabular}




\begin{tabular}{|c|c|c|}
\hline \multirow[t]{6}{*}{$\begin{array}{l}\text { SUB BAB } \\
(\text { KONSEP) }\end{array}$} & INDIKATOR & $\begin{array}{l}\text { BUTIR } \\
\text { SOAL }\end{array}$ \\
\hline & $\begin{array}{l}\text { \# Menganalisis titik didih larutan elektrolit jika molalitas } \\
\text { zat terlarut berbeda. }\end{array}$ & 8 \\
\hline & * Menentukan kenaikan titik didih larutan nonelektrolit. & 9 \\
\hline & * Menentukan kenaikan titik didih larutan elektrolit. & 10 \\
\hline & — Menentukan titik didih larutan nonelektrolit. & 11 \\
\hline & \& Menentukan titik didih larutan elektrolit. & 12 \\
\hline \multirow[t]{6}{*}{$\begin{array}{l}\text { Penurunan Titik } \\
\text { Beku }\left(\Delta \mathrm{T}_{\mathrm{f}}\right)\end{array}$} & $\begin{array}{l}\text { * Menganalisis titik beku larutan nonelektrolit jika } \\
\text { molalitas zat terlarut berbeda. }\end{array}$ & 13 \\
\hline & $\begin{array}{l}\text { \# Menganalisis titik beku larutan elektrolit jika molalitas } \\
\text { zat terlarut berbeda }\end{array}$ & 14 \\
\hline & \# Menentukan penurunan titik beku larutan nonelektrolit. & 15 \\
\hline & \# Menentukan penurunan titik beku larutan elektrolit. & 16 \\
\hline & \# Menentukan titik beku larutan nonelektrolit. & 17 \\
\hline & * Menentukan titik beku larutan elektrolit. & 18 \\
\hline \multirow[t]{6}{*}{$\begin{array}{l}\text { Tekanan Osmotik } \\
\text { Larutan }(\pi)\end{array}$} & $\begin{array}{l}\text { * Menganalisis larutan nonelektrolit yang isotonik } \\
\text { terhadap larutan elektrolit. }\end{array}$ & 19 \\
\hline & $\begin{array}{l}\text { * Menentukan larutan elektrolit yang isotonik terhadap } \\
\text { larutan nonelektrolit. }\end{array}$ & 20 \\
\hline & — Menentukan tekanan osmotik larutan nonelektrolit. & 21 \\
\hline & \# Menentukan tekanan osmotik larutan elektrolit. & 22 \\
\hline & $\begin{array}{l}\text { * Menentukan larutan nonelektrolit yang hipertonik } \\
\text { terhadap larutan nonelektrolit. }\end{array}$ & 23 \\
\hline & $\begin{array}{l}\text { \# Menentukan larutan elektrolit yang hipotonik terhadap } \\
\text { larutan elektrolit. }\end{array}$ & 24 \\
\hline
\end{tabular}

Data penelitian ini berupa data kemampuan siswa dalam pelajaran kimia pada konsep sifat koligatif larutan. Data penelitian ini dikumpulkan menggunakan tes tertulis yaitu dengan soal TKSKL diberikan kepada siswa yang menjadi subjek penelitian. Kisi-kisi instrumen atau materi diasosiasikan kepada siswa satu hari sebelum penelitian. Soal TKSKL dikerjakan siswa didalam ruangan kelas pada jam pelajaran. Hasil Jawaban siswa dikumpulkan.

Analsis kelompok pola jawaban dilakukan setelah hasil tes kemampuan siswa didapatkan dari ketiga sekolah yaitu SMA A, SMA B, dan SMA C. Data hasil tes kemampuan siswa dari ketiga sekolah ini digabung seluruhnya dengan tujuan untuk memaparkan kemampuan siswa sehingga korelasi yang akan dihasilkan dapat mewakili korelasi antar sub topik dalam pokok bahasan sifat koligatif larutan pada siswa SMA Negeri di Palangka Raya. Jawaban siswa kemudian diberikan skor "1" untuk setiap jawaban benar dan skor " 0 " untuk setiap jawaban salah.

Uji prasyarat analisis korelasi yaitu dilakukannya uji normalitas data. Uji normalitas data penting untuk dilakukan karena perhitungan statistik parametrik mempunyai asumsi yang mengatakan bahwa data yang diteliti harus berdistribusi normal. Uji normalitas data menggunakan Lilliefors Test dengan bantuan program 
SPSS dengan asumsi di antaranya adalah sampel diambil secara acak dan berskala ordinal.

Penafsiran hasil analisis didasarkan pada hipotesis. Hipotesis statistik uji normalitas dalam penelitian ini antara lain:

$\mathrm{H}_{0}$ : data berdistribusi normal.

$\mathrm{H}_{\mathrm{a}}$ : data tidak berdistribusi normal.

Ketentuan normalitas dapat menggunakan nilai D hitung terhadap nilai D tabel berdasarkan tingkat $\alpha$ sebesar 5\%. Ketentuan tersebut adalah sebagai berikut:

Jika nilai $\mathrm{D}$ hitung > D tabel, maka $\mathrm{H}_{0}$ ditolak dan data tidak berdistribusi normal. Jika nilai $\mathrm{D}$ hitung $<\mathrm{D}$ tabel, maka $\mathrm{H}_{0}$ diterima dan data berdistribusi normal).

Uji Korelasi dalam penelitian ini dianalisis dengan bantuan program SPSS. Interpretasi kedua adalah melihat signifikansi hubungan antar variabel didasarkan pada angka signifikansi (sig) berdasarkan taraf sebesar 5\% yang dihasilkan dari perhitungan menggunakan program SPSS 25 for windows dengan ketentuan sebagai berikut:

Jika signifikansi hasil hitung $<0,05$, maka hubungan antar variabel signifikan Jika signifikansi hasil hitung $>0,05$, maka hubungan antar variabel tidak signifikan

Interpretasi ketiga melihat arah korelasi. Terdapat dua jenis arah korelasi, yaitu searah dan tidak searah. Arah korelasi dapat didasarkan dari angka koefisien korelasi. Kofisien korelasi yang bernilai positif menunjukan hubungan antar variabel juga tinggi. Koefisien korelasi yang bernilai negatif menunjukkan hubungan antar variabel tidak searah. Data analisis korelasi tiap sub topik dalam pokok bahasan sifat koligatif larutan diurutkan berdasarkan nilai koefisien korelasi yang paling tinggi ke rendah dan diurutkan berdasarkan tingkat kesukaran yang didapat dari nilai rata-rata tes (mean).

Analisis deskriptif merupakan bagian dari statistik yang digunakan untuk menggambarkan atau mendeskripsikan data tanpa bermaksud untuk membuat kesimpulan tapi hanya menjelaskan kelompok data itu saja. Data yang dideskripsikan mencakup di antaranya, yaitu: (a) data kontribusi antar variabel,

(b) data mean, (c) data uji signifikan, dan (d) data korelasi antar materi pokok pelajaran.

\section{HASIL PENELITIAN DAN PEMBAHASAN}

Pengambilan data pada penelitian ini dilaksanakan pada tiga sekolah di kota Palangka Raya dengan subjek penelitian siswa kelas XII-IPA, yakni sebagai berikut:

1. SMA Negeri 2 Palangka Raya sebagai SMA A dengan total subjek 80 siswa. Pengambilan data dilaksanakan pada tanggal 21 dan 27 Februari 2019.

2. SMA Negeri 3 Palangka Raya sebagai SMA B dengan total subjek 59 siswa. Pengambilan data dilaksanakan pada tanggal 1 dan 6 Maret 2019. 
3. SMA Negeri 4 Palangka Raya sebagai SMA C dengan total subjek 82 siswa.

Pengambilan data dilaksanakan pada tanggal 5 dan 7 Maret 2019.

Proses pengambilan data diawali dengan pemberian tes tertulis berupa pilihan ganda sebanyak 24 soal yang terdiri dari 6 soal pada setiap indikator tentang penurunan tekanan uap larutan (PTUL), kenaikan titik didih larutan (KTDL), penurunan titik beku larutan (PTBL), dan tekanan osmotik larutan (TOL). Pemberian soal dilakukan dalam satu kali pertemuan. Alokasi waktu yang digunakan untuk proses siswa menjawab soal pilihan ganda berlangsung selama 135 menit untuk setiap kelas dengan penskoran untuk tiap soal adalah bernilai satu (1) untuk jawaban benar dan skor nol (0) untuk jawaban salah adapun skor maksimum pada tes ini adalah 100 .

Data hasil uji normalitas menunjukkan bahwa D hitung (statistic) untuk setiap sub topik PTUL, KTDL, PTBL, dan TOL memiliki nilai lebih dari 0,200 dan harga $\mathrm{D}$ tabel pada taraf $\alpha=5 \%$ sebesar 0,059 . Artinya, D hitung $>\mathrm{D}$ tabel menunjukkan bahwa $\mathrm{H}_{0}$ ditolak dan data berdistribusi tidak normal, sehingga data penelitian ini dianalisis dengan uji nonparametrik menggunakan uji korelasi Kendall (Kendall's tau-b Coefficient of Correlation).

Data dari hasil jawaban siswa pada tiap sub topik dianalisis menggunakan bantuan program SPSS 25 for windows, kemudian didapatkan nilai koefisien korelasi antar sub topik, hasil korelasi terdapat pada Tabel 15.

Korelasi antar sub topik memiliki nilai koefisien korelasi paling kecil sebesar 0,7 dan yang paling besar adalah 1, artinya termasuk ke dalam kriteria nilai korelasi 0,7 - 0,8 dan 0,9 - 1 dengan tingkat korelasi dari kuat sampai sangat kuat. Hasil analisis dari nilai koefisien korelasi bernilai positif yang menunjukkan hubungan antar variabel searah.

Keputusan: Pada nilai sig. hitung dari hubungan antar variabel dalam tabel sebesar 0,007. Nilai sig. hitung 0,007 <0,05, maka hubungan antar sub topik dalam pokok bahasan sifat koligatif larutan adalah signifikan.

Pada silabus, urutan penyajian materi dalam pokok bahasan sifat koligatif larutan dimulai dari (1) PTUL, dilanjutkan materi (2) KTDL, kemudian materi (3) PTBL, dan materi terakhir adalah (4) TOL. Urutan penyajian materi pada silabus ditentukan oleh para pakar berdasarkan karakteristik masing-masing materi. 
Tabel 15. Korelasi

\begin{tabular}{|c|c|c|c|c|c|c|}
\hline \multicolumn{7}{|c|}{ Correlations } \\
\hline & & & PTUL & KTDL & PTBL & TOL \\
\hline \multirow{12}{*}{$\begin{array}{l}\text { Kendall's } \\
\text { tau_b }\end{array}$} & \multirow[t]{3}{*}{ PTUL } & Correlation Coefficient & 1.000 & $.803^{* *}$ & $.712^{* *}$ & $.803^{* *}$ \\
\hline & & Sig. (2-tailed) & & .007 & .005 & .002 \\
\hline & & $\mathrm{N}$ & 221 & 221 & 221 & 221 \\
\hline & \multirow[t]{3}{*}{ KTDL } & Correlation Coefficient & $.803^{* *}$ & 1.000 & $.936^{* *}$ & $.851^{* *}$ \\
\hline & & Sig. (2-tailed) & .002 & & .007 & .004 \\
\hline & & $\mathrm{N}$ & 221 & 221 & 221 & 221 \\
\hline & \multirow[t]{3}{*}{ PTBL } & Correlation Coefficient & $.712^{* *}$ & $.936^{* *}$ & 1.000 & $.752^{* *}$ \\
\hline & & Sig. (2-tailed) & .003 & .006 & & .004 \\
\hline & & $\mathrm{N}$ & 221 & 221 & 221 & 221 \\
\hline & \multirow[t]{3}{*}{ TOL } & Correlation Coefficient & $.873^{* *}$ & $.851^{* *}$ & $.752^{* *}$ & 1.000 \\
\hline & & Sig. (2-tailed) & .004 & .007 & .005 & \\
\hline & & $\mathrm{N}$ & 221 & 221 & 221 & 221 \\
\hline
\end{tabular}

Deskripsi Korelasi Antar Sub Topik dalam Pokok Bahasan Sifat Koligatif Larutan Berdasarkan Nilai Koefisien Korelasi pada Seluruh Sekolah

Berdasarkan data koefisien korelasi Kendall tau-b pada Tabel 15, kedekatan hubungan antar topik dalam pokok bahasan sifat koligatif larutan dapat $\begin{array}{lll}\text { diinformasikan } & \text { pada } & \text { Gambar }\end{array}$

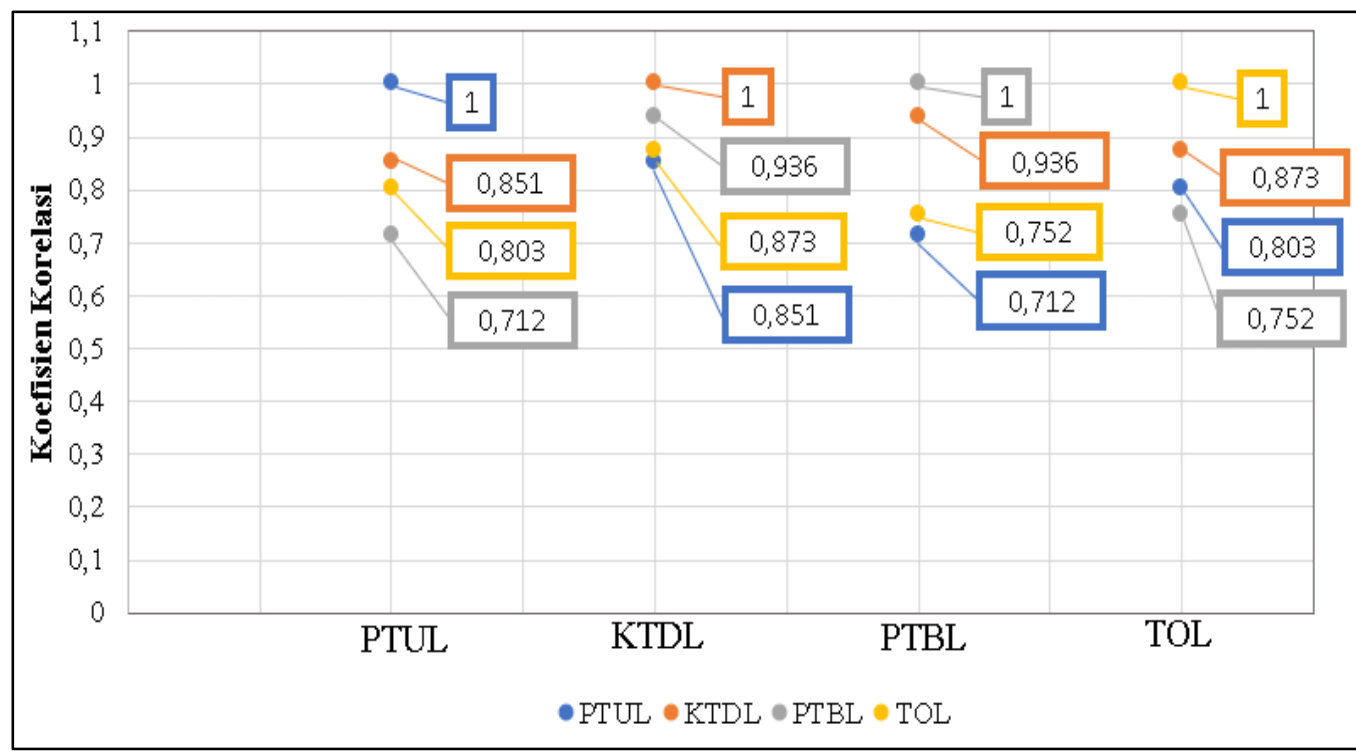

Gambar 9. Koefesien korelasi antar topik dalam pokok bahasan sifat koligatif larutan

Korelasi antar sub topik dalam pokok bahasan sifat koligatif larutan terbagi menjadi 4 hubungan, yaitu hubungan antar sub topik PTUL, KTDL, PTBL, dan TOL. Titik yang digunakan sebagai batas korelasi antar sub topik dengan sub topik lainnya adalah titik dengan nilai koefisen korelasi "1" pada masing-masing sub topik. Gambar 9 menunjukkan kedekatan antar sub topik dengan nilai koefisien korelasi terbesar yaitu KTDL, PTBL, TOL, dan PTUL. 
Kekuatan korelasi dan kedekatan antar sub topik bisa dilihat dari besarnya nilai koefisen korelasi suatu sub topik dengan sub topik lainnya, nilai koefisien korelasi yang semakin mendekati "1", maka hubungan akan semakin kuat. Nilai koefisien yang semakin menjauhi "1", maka hubungannya akan semakin lemah. Arah hubungan dari korelasi antar sub topik dalam pokok bahasan sifat koligatif larutan ini juga dapat diinterpretasikan pada Gambar 10.

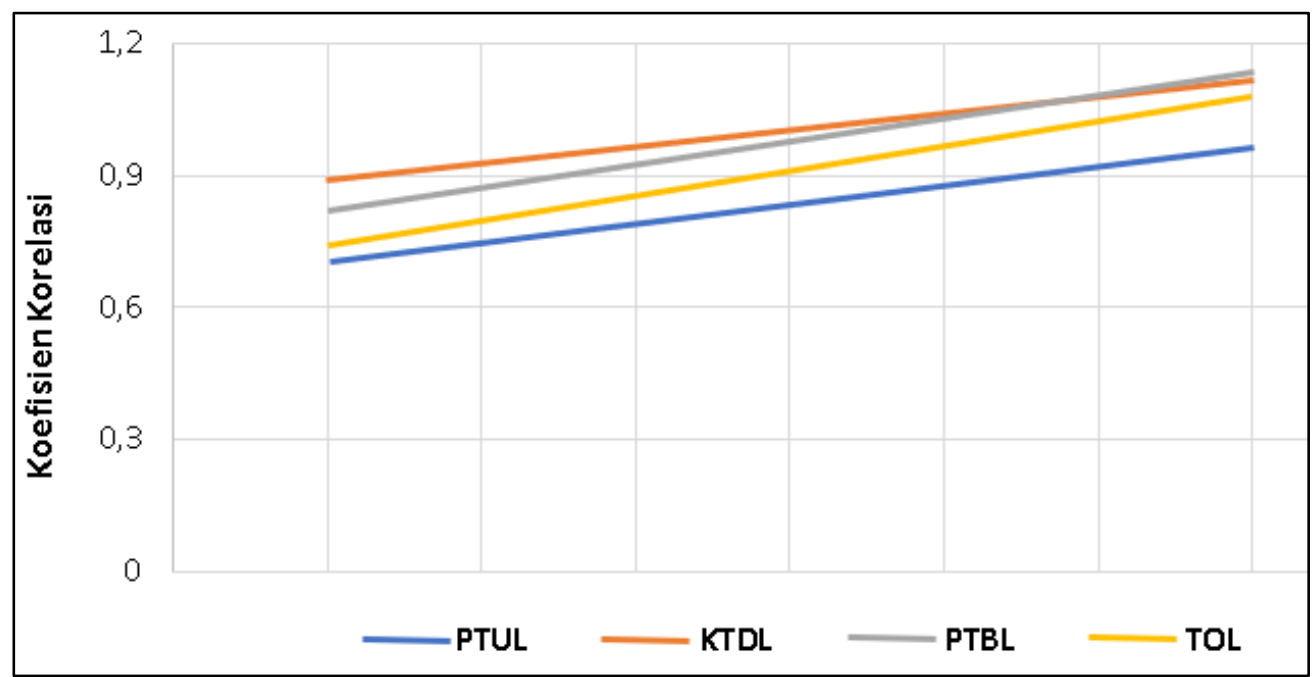

Gambar 10. Arah korelasi pada seluruh sub topik.

Data pada Gambar 10 menerangkan bahwa korelasi pada seluruh sub topik memiliki arah yang sama dan bernilai positif. Hal ini menandakan bahwa pemahaman konsep pada sub topik yang satu akan berpengaruh pada pemahaman konsep pada sub topik yang lain. Sub topik KTDL dan PTBL memiliki kedekatan yang kuat, terlihat dari garis kedua topik ini yang semakin berimpit. Pada sub topik TOL dan PTUL walaupun searah tetapi memiliki kedekatan yang lemah terhadap ke dua topik lainnya, dapat dilihat dari garis TOL dan garis PTUL pada grafik yang berada jauh dari sub topik KTDL dan PTBL.

Deskripsi urutan penyajian materi berdasarkan kekuatan dan kedekatan hubungan dari nilai koefisien korelasi antar sub topik dalam pokok bahasan sifat koligatif larutan terdapat pada Gambar 11. 


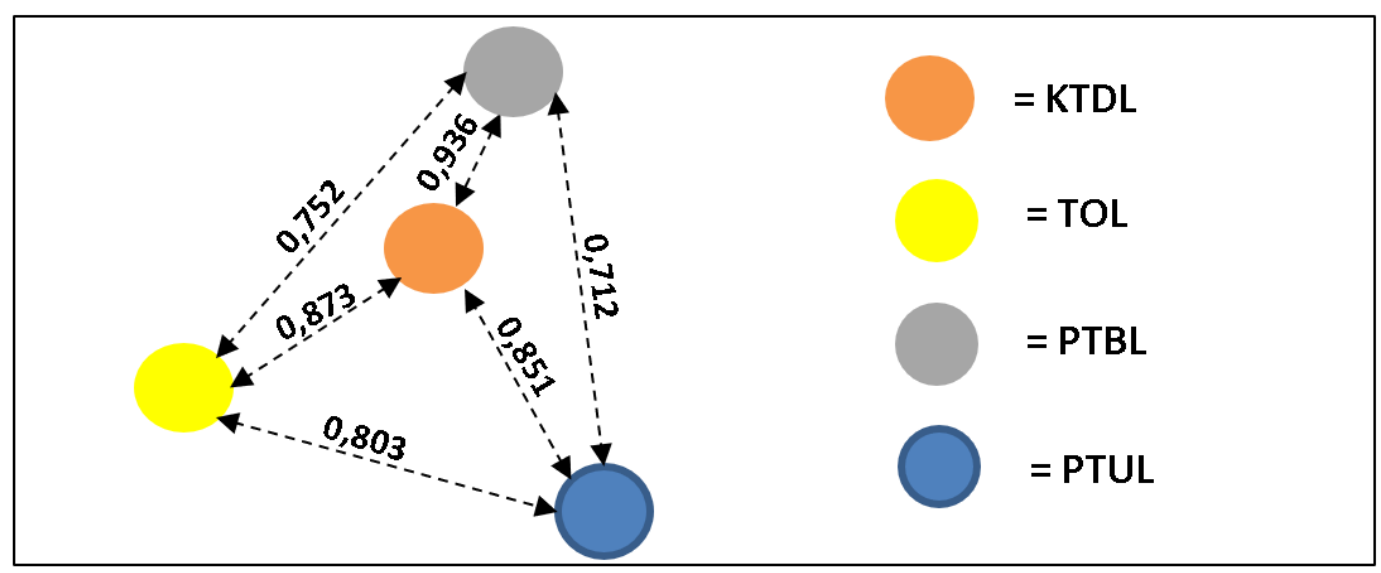

Gambar 11. Hubungan antar koefesien korelasi

Jarak antara garis putus-putus (garis hubungan) yang satu dengan yang lain digambarkan berdasarkan nilai koefisien korelasi pada Tabel 15. Garis hubungan yang semakin pendek menunjukkan semakin besar nilai koefisien korelasinya. Garis yang semakin panjang menunjukkan semakin kecil nilai koefisien korelasinya.

Gambar 11 menggambarkan sub topik KTDL menjadi pusat untuk ketiga sub topik lainnya yang berarti sub topik KTDL sebagai materi pertama dalam pokok bahasan sifat koligatif sangat memungkinkan untuk diterapkan kepada siswa, melalui pendekatan secara eksperimen maupun konsep. Berdasarkan pendekatan secara eksperimen, bahan dan alat yang diperlukan untuk percobaan sub topik KTDL sederhana dan mudah untuk didapatkan. Percobaan yang mendukung pendekatan ini adalah jika ke dalam air murni dilarutkan suatu zat yang sukar menguap, maka pada suhu $100^{\circ} \mathrm{C}$ tekanan uap air belum mencapai 1 atm yang berarti air belum mendidih. Agar dapat mendidih (tekanan uap air mencapai 1 atm), maka diperlukan suhu yang lebih tinggi. Besarnya kenaikan suhu yang disebut dengan kenaikan titik didih larutan $\left(\Delta \mathrm{T}_{\mathrm{b}}\right)$ yang dapat diukur menggunakan alat termometer, sedangkan pendekatan secara konsep kenaikan titik didih larutan dan titik didih larutan berbanding lurus dengan konsentrasi molalitas (m).

Sub topik KTDL paling dekat dengan sub topik PTBL (koefisien korelasi $=0,936$ ) menunjukkan bahwa kedua sub topik ini memiliki hubungan korelasi yang sangat kuat. Berdasarkan nilai korelasi sub topik PTBL disajikan pada materi yang kedua setelah KTDL dan ini sangat memungkinkan untuk diterapkan kepada siswa melalui pendekatan secara eksperimen maupun konsep. Secara eksperimen bahan dan alat yang diperlukan untuk percobaan ini sederhana dan mudah untuk didapatkan. Percobaan yang mendukung pendekatan ini adalah jika ke dalam air murni dilarutkan suatu zat terlarut, maka pada suhu $0^{\circ} \mathrm{C}$ air belum membeku. Agar dapat membeku, maka diperlukan suhu yang lebih rendah. Besarnya penurunan suhu itulah disebut dengan titik beku larutan $\left(\Delta \mathrm{T}_{\mathrm{f}}\right)$ yang dapat diukur menggunakan alat termometer, sedangkan pendekatan secara konsep 
penurunan titik beku larutan dan titik beku larutan sama dengan sub topik KTDL, yakni berbanding lurus dengan konsentrasi molalitas (m).

Selanjutnya sub topik KTDL jauh dengan sub topik TOL (koefisien korelasi $=0,873$ ) dan yang paling jauh dengan sub topik PTUL (koefisien korelasi $=0,851$ ) yang menunjukkan korelasi sub topik TOL dan PTBL lemah terhadap sub topik KTDL. Berdasarkan nilai korelasi sub topik TOL dan sub topik PTUL secara berurutan berada pada penyajian materi ketiga dan keempat. Berdasarkan pendekatan secara eksperimen ataupun konsep pada kedua sub topik ini sangat berbeda dengan sub topik KTDL dan PTBL yang memiliki materi prasyarat yang sama.

Pendekatan secara eksperimen pada sub topik TOL memerlukan bahan dan alat yang kompleks. Percobaan yang mendukung pendekatan terhadap sub topik TOL adalah dua larutan dengan konsentrasi yang berbeda dipisahkan dengan membran semipermeabel pada bejana U. Berdasarkan hasil percobaan permukaan larutan (A) sedikit demi sedikit naik, tetapi suatu saat akan berhenti karena adanya tekanan hidrostatis yang menahan gerak molekul-molekul pelarut berikutnya. Tekanan hidrostatis $(\Delta h)$ yang mengimbangi tekanan yang diakibatkan oleh gerak molekul-molekul pelarut yang masuk dari B ke larutan A melewati dinding semipermeabel disebut tekanan osmotik larutan. Molekul-molekul pelarut dari larutan encer akan menuju ke larutan yang lebih pekat hingga kesetimbangan tekanan osmotik tercapai, sedangkan pendekatan secara konsep tekanan osmotik larutan berbanding lurus dengan konsentrasi molaritas.

Pendekatan secara eksperimen pada sub topik PTUL memerlukan bahan dan alat yang kompleks. Percobaan terhadap tekanan uap antara lain tekanan yang dihasilkan oleh uap pada temperatur tertentu secara termodinamika setimbang dengan fase kondensasi dalam sistem tertutup. Tekanan uap larutan dalam percobaan ini dapat diukur dengan alat manometer. Tekanan uap larutan selalu lebih rendah dibandingkan dengan tekanan uap pelarut murni karena adanya zat terlarut nonvolatil yang menyebabkan penurunan tekanan uap larutan, sedangkan secara konsep tekanan uap larutan berbanding lurus dengan konsentrasi fraksi mol pelarut dan penurunan tekanan uap larutan berbanding lurus dengan konsentrasi fraksi mol zat terlarut.

Nilai koefisien korelasi antar sub topik dalam pokok bahasan sifat koligatif larutan dapat disusun mulai dari materi dengan koefisien korelasi yang paling signifikan. Susunan materi dari masing-masing sub topik berdasarkan nilai koefisien korelasi adalah sebagai Gambar 12 berikut. 


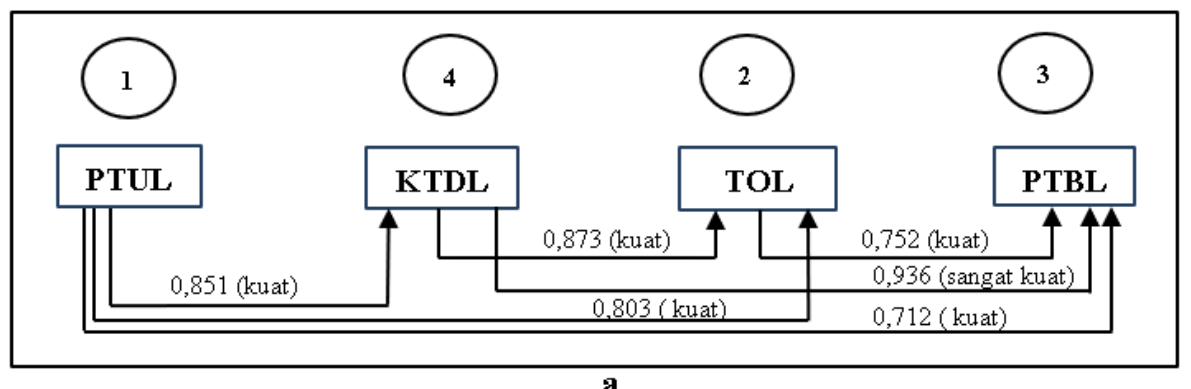

$\mathbf{a}$

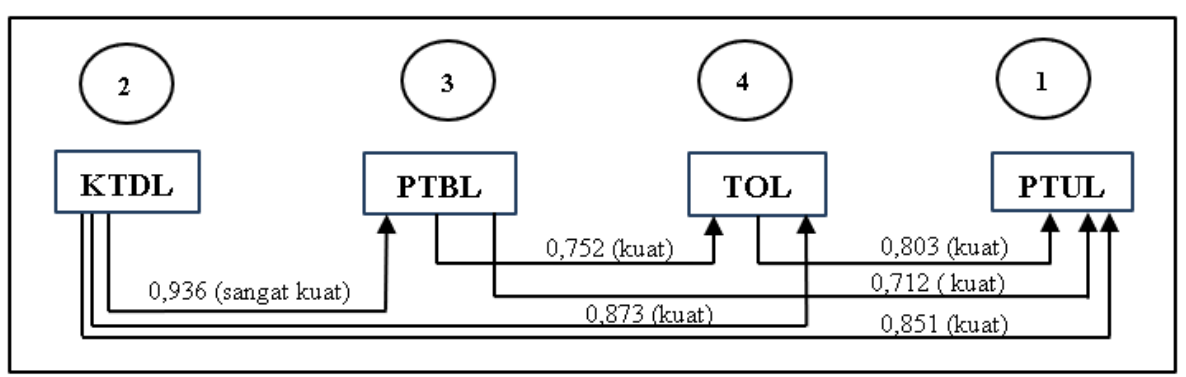

b

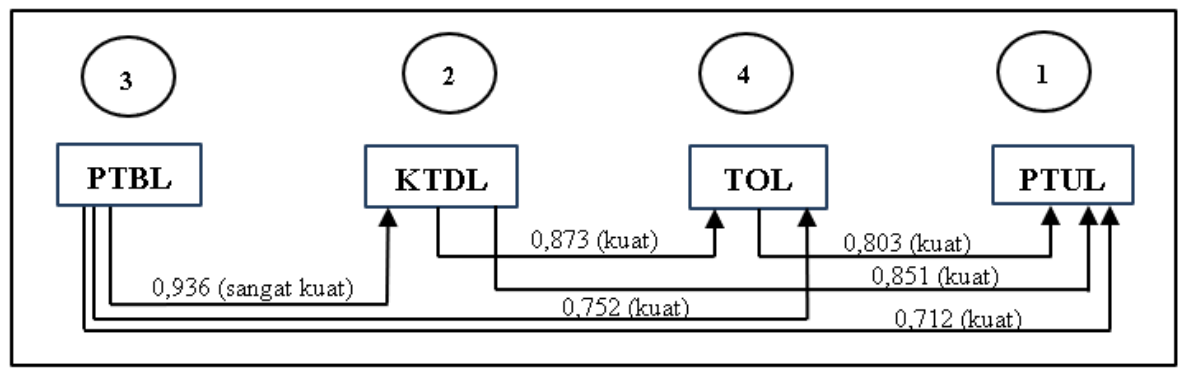

c

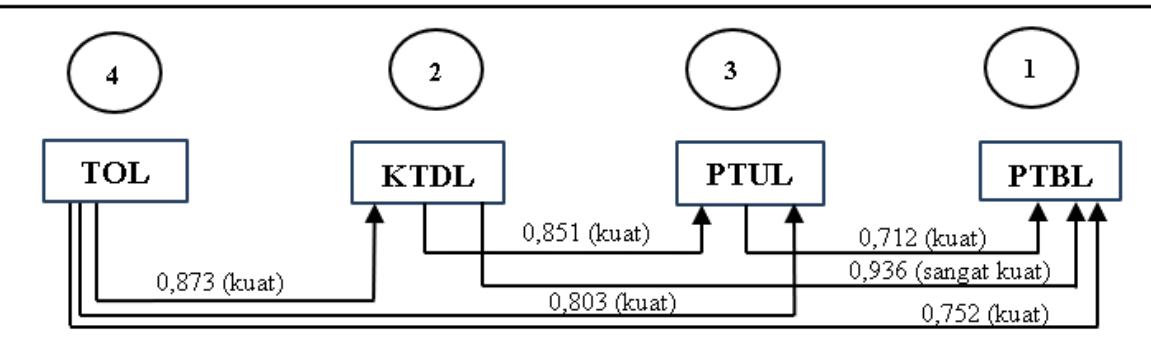

d

Gambar 12. Susunan materi dari masing-masing sub topik berdasarkan nilai koefisien korelasi

Urutan materi pembelajaran secara hierarkis menggambarkan urutan yang bersifat berjenjang dari bawah ke atas atau dari atas ke bawah. Urutan materi pembelajaran yang bersifat berjenjang dari atas ke bawah atau dari materi yang sulit ke materi yang mudah. Urutan materi pembelajaran yang bersifat berjenjang dari bawah ke atas atau dari materi yang mudah ke materi yang sulit berdasarkan nilai koefisien korelasi seluruh sekolah terdapat pada Gambar 12c dan Gambar 12d. Pada Gambar 12c mengartikan bahwa materi (1) PTBL dan (2) KTDL sebagai materi yang tergolong mudah yang diajarkan kepada siswa, kemudian bertahap menuju materi yang lebih sulit (3) TOL dan (4) PTUL. Pada Gambar 12d 
mengartikan bahwa materi (1) TOL sebagai materi yang tergolong mudah yang diajarkan kepada siswa, kemudian bertahap menuju materi yang lebih sulit, yakni (2) KTDL, (3) PTUL, dan (4) PTBL. Berdasarkan besarnya nilai koefisien korelasi dan karakteristik dari masing-masing materi, maka urutan materi pada Gambar 12c sangat memungkinkan untuk diterapkan ke siswa.

Berdasarkan data analisis korelasi antar sub topik pokok bahasan sifat koligatif larutan diurutkan berdasarkan nilai koefisien korelasi yang terbesar ke yang terkecil. Urutan penyajian materi berdasarkan nilai koefisien korelasi yang paling signifikan adalah:

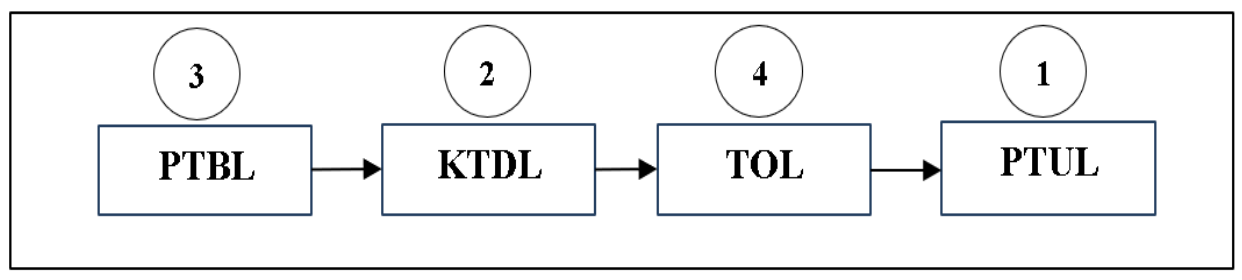

\section{Deskripsi Korelasi Antar Sub Topik Dalam Pokok Bahasan Sifat Koligatif Larutan Berdasarkan Nilai Koefisien Korelasi pada Siswa Laki-Laki dan Perempuan}

Urutan penyajian materi berdasarkan koefisien korelasi pada SMA C berbeda dengan urutan penyajian materi berdasarkan silabus maupun koefisien korelasi secara keseluruhan, sedangkan dua sekolah sebelumnya memiliki urutan penyajian materi yang sama dengan urutan penyajian materi seperti fenomena keseluruhan.

Perbedaan urutan ini kemungkinan disebabkan oleh beberapa hal, salah satunya kesulitan siswa dalam menjawab butir soal pada topik tertentu. Kemampuan siswa dalam menjawab butir soal dipengaruhi oleh pengetahuan dan pemahaman konsep yang dimiliki. Faktor yang dapat mempengaruhi pemahaman konsep oleh siswa adalah bahasa, jenis kelamin, dan jenjang kelas (Sidauruk, 2005).

Analisis korelasi kemudian dilakukan pada siswa 29 laki-laki dan 53 siswa perempuan SMA C. Kedekatan hubungan antar topik dalam pokok bahasan sifat koligatif larutan dapat diinformasikan pada Gambar 29. 


\begin{tabular}{|c|c|c|c|c|c|c|}
\hline \multicolumn{7}{|c|}{ Correlations } \\
\hline & & & PTUL & KTDL & PTBL & TOL \\
\hline \multirow{12}{*}{$\begin{array}{l}\text { Kendall's } \\
\text { tau_b }\end{array}$} & \multirow[t]{3}{*}{ PTUL } & Correlation Coefficient & 1.000 & .674 & .524 & .608 \\
\hline & & Sig. (2-tailed) & & .000 & .000 & .000 \\
\hline & & $\mathrm{N}$ & 29 & 29 & 29 & 29 \\
\hline & \multirow[t]{3}{*}{ KTDL } & Correlation Coefficient & .674 & 1.000 & .783 & .714 \\
\hline & & Sig. (2-tailed) & .000 & & .000 & .000 \\
\hline & & $\mathrm{N}$ & 29 & 29 & 29 & 29 \\
\hline & \multirow[t]{3}{*}{ PTBL } & Correlation Coefficient & .524 & .783 & 1.000 & .576 \\
\hline & & Sig. (2-tailed) & .000 & .000 & & .000 \\
\hline & & $\mathrm{N}$ & 29 & 29 & 29 & 29 \\
\hline & \multirow[t]{3}{*}{ TOL } & \multirow{3}{*}{$\begin{array}{l}\text { Correlation Coefficient } \\
\text { Sig. (2-tailed) } \\
\mathrm{N}\end{array}$} & .608 & .714 & .576 & 1.000 \\
\hline & & & .000 & .000 & .000 & \\
\hline & & & 29 & 29 & 29 & 29 \\
\hline \multicolumn{7}{|l|}{$\overline{1,1}$} \\
\hline \multicolumn{7}{|l|}{1} \\
\hline \multicolumn{7}{|l|}{$\begin{array}{r}0,9 \\
\mathbf{w}^{0,8}\end{array}$} \\
\hline \multicolumn{7}{|c|}{$0,0,6 / 4$} \\
\hline 0,6 & & 0,608 & 0,674 & \multicolumn{2}{|c|}{0,524} & \\
\hline 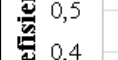 & & 0,524 & & & & 0,576 \\
\hline 0,3 & & & & & & \\
\hline \multicolumn{7}{|l|}{$\begin{array}{r}0,3 \\
0,2\end{array}$} \\
\hline \multicolumn{7}{|l|}{0,1} \\
\hline 0 & & \multirow{2}{*}{ PTUL } & & PTBL & \multirow{2}{*}{\multicolumn{2}{|c|}{ TOL }} \\
\hline & & & 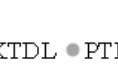 & & & \\
\hline
\end{tabular}

Gambar 29. Koefesien korelasi antar topik dalam pokok bahasan sifat koligatif larutan siswa laki-laki.

Arah hubungan dari korelasi antar topik dalam pokok bahasan sifat koligatif larutan ini juga dapat diinterpretasikan pada Gambar 30.

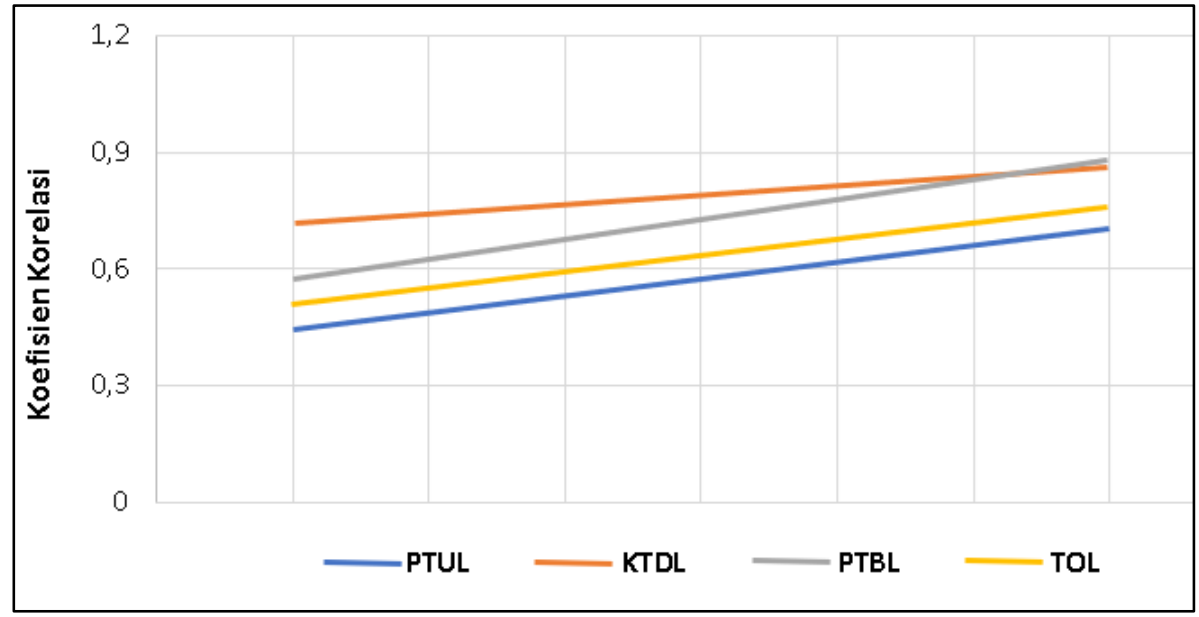

Gambar 30. Arah korelasi antar topik dalam pokok bahasan sifat koligatif larutan pada siswa laki-laki. 
Berdasarkan data koefisien korelasi pada Tabel 19, kekuatan dan kedekatan hubungan antar topik dalam pokok bahasan sifat koligatif larutan pada siswa laki-laki SMA C terdapat pada Gambar 31.

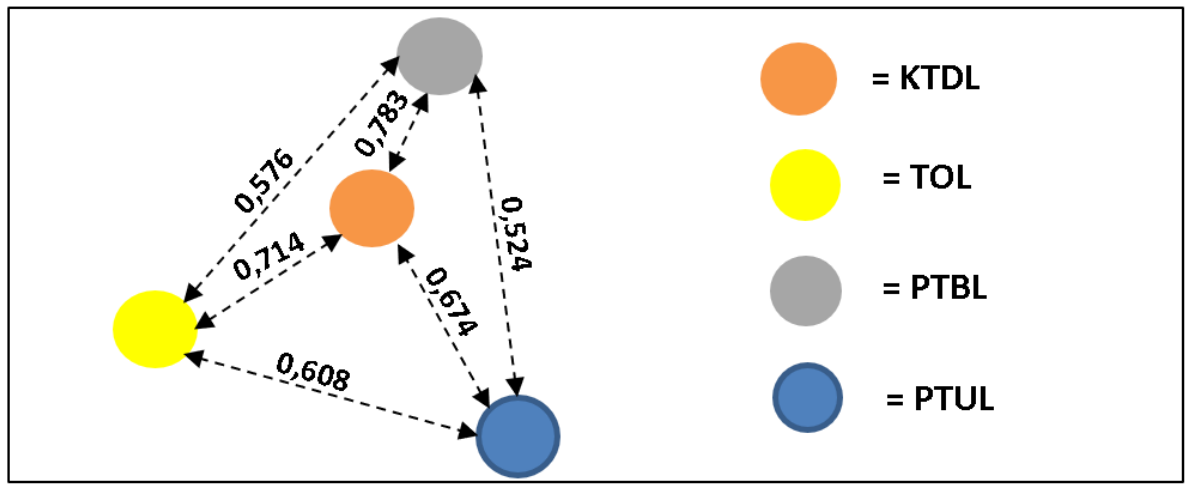

Gambar 31. Korelasi antar topik dalam pokok bahasan sifat koligatif larutan pada siswa laki-laki SMA C

Gambar 31 menunjukkan sub topik KTDL yang menjadi pusat untuk tiga topik yang lain. Topik KTDL paling dekat dengan sub topik PTBL (korelasi = 0,783 ), selanjutnya dekat dengan sub topik TOL (korelasi $=0,714$ ), dan yang paling jauh dengan topik PTUL (korelasi $=0,674$ ).

Berdasarkan data analisis korelasi antar sub topik pokok bahasan sifat koligatif larutan diurutkan berdasarkan nilai koefisien korelasi yang terbesar ke yang terkecil. Urutan penyajian materi berdasarkan nilai koefisien korelasi yang paling signifikan adalah:

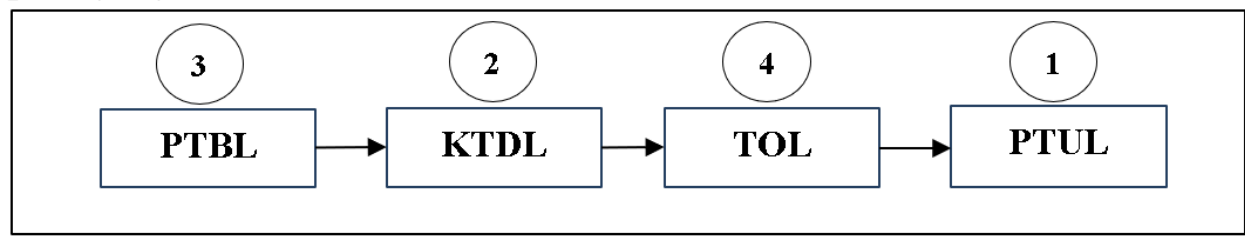

Urutan penyajian materi pada siswa laki-laki SMA C berdasarkan nilai koefisien korelasi sama bila dibandingkan dengan urutan penyajian materi berdasarkan silabus dan koefisien korelasi secara keseluruhan. Adapun nilai koefisien korelasi siswa perempuan SMA C adalah sebagai berikut.

\begin{tabular}{|c|c|c|c|c|c|c|}
\hline \multicolumn{7}{|c|}{ Correlations } \\
\hline & & & PTUL & KTDL & PTBL & TOL \\
\hline \multirow{12}{*}{$\begin{array}{l}\text { Kendall's } \\
\text { tau_b }\end{array}$} & \multirow[t]{3}{*}{ PTUL } & Correlation Coefficient & 1.000 & .754 & .608 & .652 \\
\hline & & Sig. (2-tailed) & & .000 & .000 & .000 \\
\hline & & $\mathrm{N}$ & 53 & 53 & 53 & 53 \\
\hline & \multirow[t]{3}{*}{ KTDL } & Correlation Coefficient & .754 & 1.000 & .813 & .693 \\
\hline & & Sig. (2-tailed) & .000 & & .000 & .000 \\
\hline & & $\mathrm{N}$ & 53 & 53 & 53 & 53 \\
\hline & \multirow[t]{3}{*}{ PTBL } & Correlation Coefficient & .608 & .813 & 1.000 & .589 \\
\hline & & Sig. (2-tailed) & .000 & .000 & & .000 \\
\hline & & $\mathrm{N}$ & 53 & 53 & 53 & 53 \\
\hline & \multirow[t]{3}{*}{ TOL } & Correlation Coefficient & .652 & .693 & .589 & 1.000 \\
\hline & & Sig. (2-tailed) & .000 & .000 & .000 & \\
\hline & & $\mathrm{N}$ & 53 & 53 & 53 & 53 \\
\hline
\end{tabular}




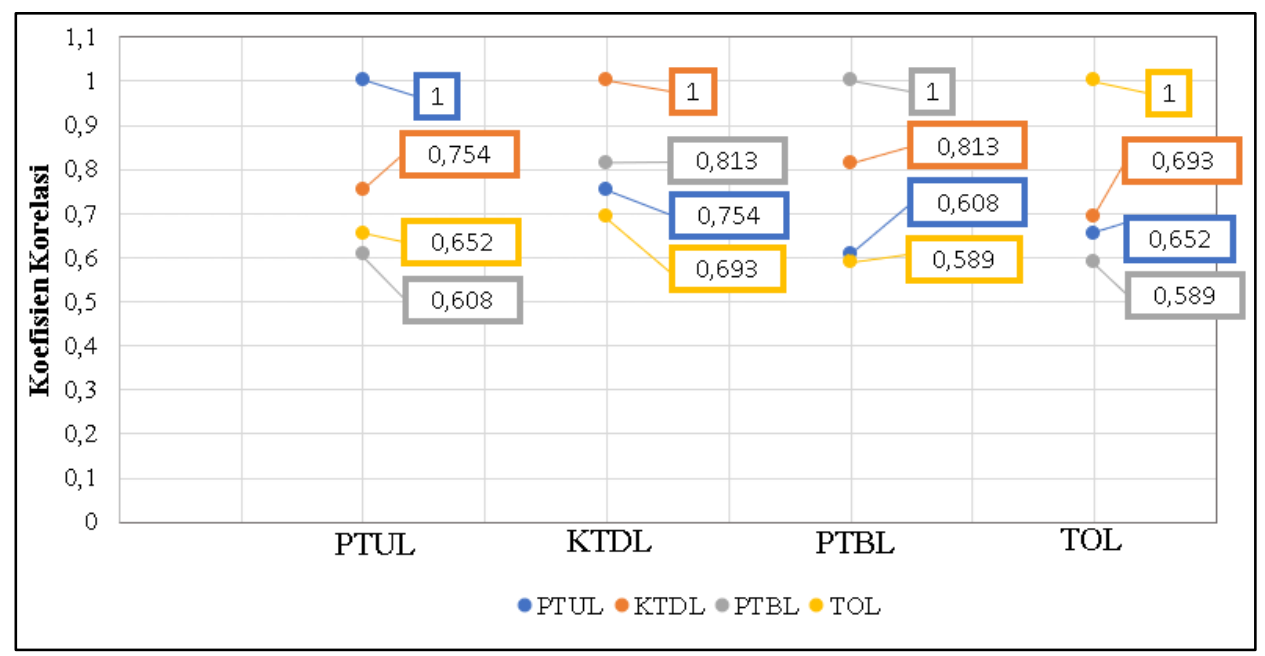

Gambar 32. Koefesien korelasi antar topik dalam pokok bahasan sifat koligatif larutan siswa perempuan.

Arah hubungan dari korelasi antar sub topik dalam pokok bahasan sifat koligatif larutan ini juga dapat diinterpretasikan pada Gambar 35.

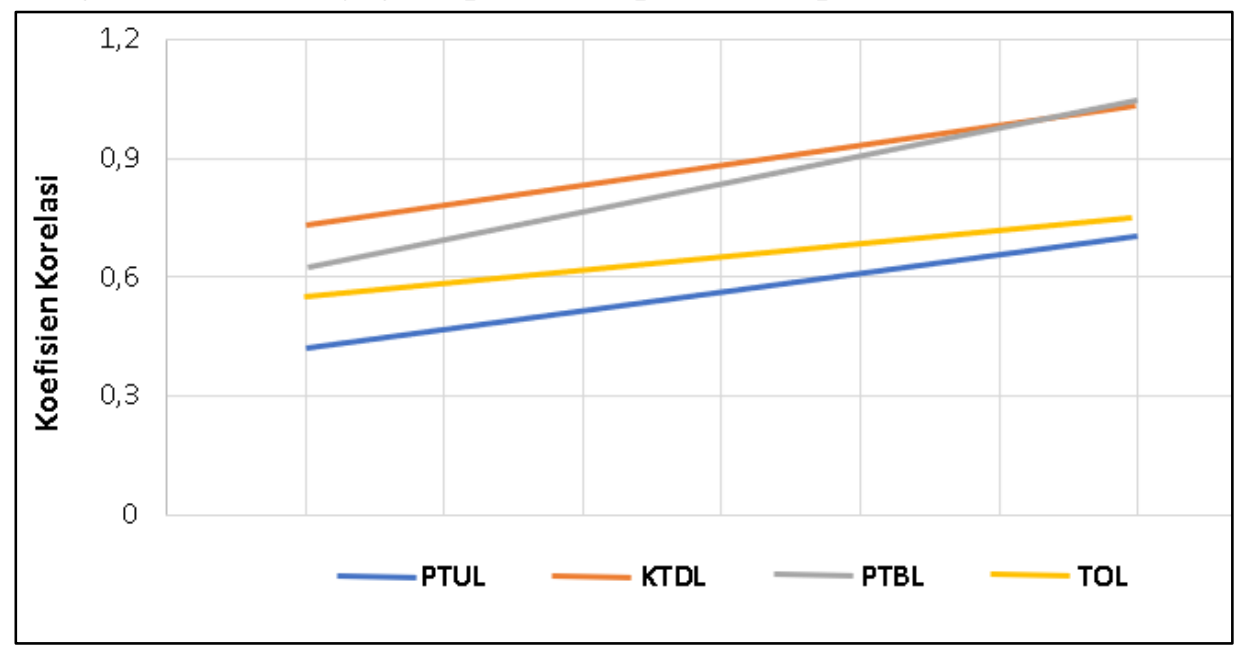

Gambar 35. Arah korelasi antar topik dalam pokok bahasan sifat koligatif larutan pada siswa perempuan.

Deskripsi urutan penyajian materi berdasarkan kekuatan dan kedekatan dari nilai koefisien korelasi antar sub topik dalam pokok bahasan sifat koligatif larutan, dapat diinterpretasikan pada Gambar 36. 


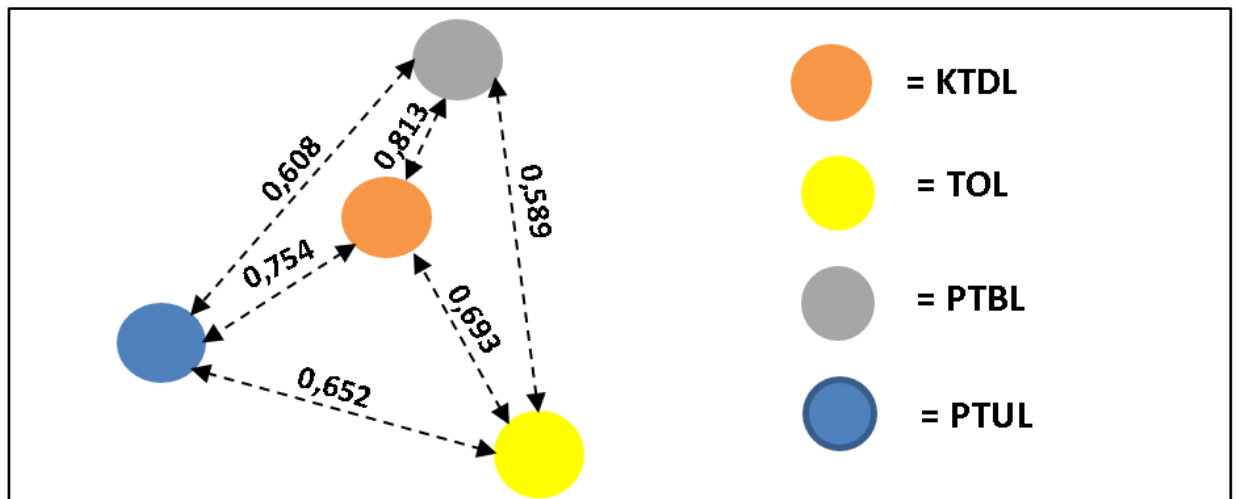

Gambar 36. Korelasi antar topik dalam pokok bahasan sifat koligatif larutan pada siswa laki-laki SMA C

Jarak antara garis putus-putus (garis hubungan) yang satu dengan yang lain digambarkan berdasarkan nilai koefisien korelasi pada Tabel 20, garis hubung yang semakin pendek menunjukkan semakin besar nilai koefisien korelasinya dan garis hubung yang semakin panjang menunjukkan semakin kecil nilai koefisien korelasinya. Gambar 36 menunjukkan topik KTDL yang menjadi pusat untuk tiga topik yang lain. Topik KTDL paling dekat dengan topik PTBL (korelasi $=0,813$ ), selanjutnya dekat dengan topik PTUL (korelasi $=0,754$ ), dan yang paling jauh dengan topik TOL (korelasi $=0,652$ ).

Berdasarkan data analisis korelasi antar sub topik pokok bahasan sifat koligatif larutan diurutkan berdasarkan nilai koefisien korelasi yang terbesar ke yang terkecil. Urutan penyajian materi berdasarkan nilai koefisien korelasi yang paling signifikan adalah:

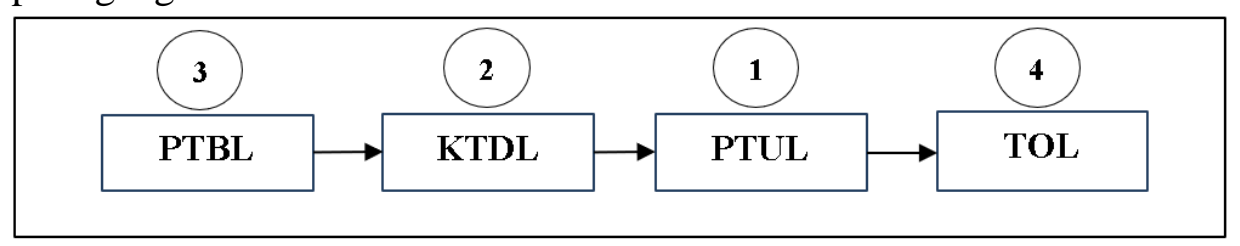

Urutan penyajian materi pada siswa perempuan SMA C berbeda bila dibandingkan dengan urutan penyajian materi berdasarkan koefisien korelasi secara keseluruhan. Perbedaan urutan penyajian materi pada siswa perempuan dan jumlah siswa perempuan yang lebih dominan ini lah yang membuat urutan penyajian materi berdasarkan nilai koefisien korelasi pada SMA C berbeda dengan dua sekolah lainnya dan secara keseluruhan. Perbedaan urutan penyajian materi ini terletak pada sub topik TOL dan PTUL. Berdasarkan nilai koefisien korelasinya siswa laki-laki lebih mudah untuk mempelajari sub topik TOL terlebih dahulu, kemudian mempelajari sub topik PTUL. Pada siswa perempuan berdasarkan nilai koefisien korelasinya lebih mudah untuk mempelajari sub topik PTUL terlebih dahulu, kemudian mempelajari sub topik TOL. 


\section{Deskripsi Korelasi Antar Sub Topik Dalam Pokok Bahasan Sifat Koligatif Larutan Berdasarkan Nilai Rata-rata Tes (mean) pada Seluruh Sekolah}

Nilai rata-rata tes (mean) yang tinggi menunjukkan kemudahan siswa dalam menjawab soal tes, jadi semakin tinggi nilai rata-rata tes (mean) materi tersebut dianggap semakin mudah untuk dipelajari. Nilai rata-rata tes (mean) yang rendah menunjukkan kesulitan siswa dalam menjawab soal tes, jadi semakin tinggi rendah rata-rata tes (mean) materi tersebut dianggap semakin sulit untuk dipelajari. Hasil analisis mean siswa pada seluruh sampel sekolah terdapat pada Tabel 23.

\section{Tabel 23. Hasil Analisis Statistik}

\begin{tabular}{|c|c|c|c|c|c|}
\hline \multicolumn{6}{|c|}{ Statistics } \\
\hline & & PTUL & KTDL & PTBL & TOL \\
\hline \multirow[t]{2}{*}{$\mathrm{N}$} & Valid & 221 & 221 & 221 & 221 \\
\hline & Missing & 0 & 0 & 0 & 0 \\
\hline \multicolumn{2}{|c|}{ Mean } & 40.61 & 59.73 & 54.82 & 46.32 \\
\hline \multicolumn{2}{|c|}{ Std. Deviation } & 4.503 & 5.467 & 5.184 & 4.876 \\
\hline \multicolumn{2}{|c|}{ Minimum } & 0 & 0 & 0 & 0 \\
\hline \multicolumn{2}{|c|}{ Maximum } & 20 & 20 & 20 & 20 \\
\hline
\end{tabular}

Data pada Tabel 23 menunjukkan bawa nilai mean terendah ada pada sub topik PTUL dan nilai mean tertinggi ada pada sub topik KTDL, sehingga dapat disimpulkan bahwa semakin tinggi nilai rata-rata (mean) hasil tes siswa maka semakin mudah sub topik pelajaran tersebut, sebaliknya semakin rendah nilai ratarata (mean) hasil tes maka semakin sulit sub topik pelajaran tersebut. Urutan tingkat kesukaran (mean) antar sub topik dalam pokok bahasan sifat koligatif larutan, yaitu:

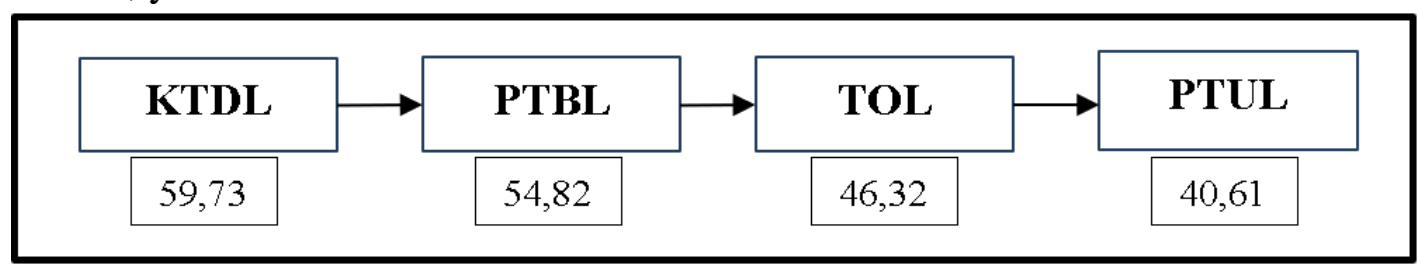

Hasil penelitian menunjukkan urutan penyajian materi berdasarkan mean secara keseluruhan dimulai dari materi dari yang termudah (mean tinggi) hingga tersulit (mean rendah) dimulai dari KTDL, PTBL, TOL, dan PTUL. Urutan penyajian materi ini sama dengan urutan penyajian materi secara keseluruhan berdasarkan nilai koefisien korelasi (kedekatan antar materi). Hasil penelitian ini secara dominan menunjukkan urutan penyajian materi dalam pokok bahasan sifat koligatif larutan dimulai dari KTDL, PTBL, TOL, dan PTUL. 


\section{KESIMPULAN}

Kesimpulan yang diperoleh dari hasil penelitian korelasi antar sub topik dalam pokok bahasan sifat koligatif larutan pada siswa kelas XII-IPA SMA Negeri Palangka Raya tahun ajaran 2018/2019, yaitu: (1) Urutan penyajian silabus adalah PTUL, KTDL, PTBL, dan TOL. Urutan penyajian materi pokok bahasan sifat koligatif larutan pada siswa kelas XII-IPA SMA Negeri Palangka Raya tahun ajaran 2018/2019 berdasarkan nilai koefisien korelasi hasil tes kemampuan pada seluruh sekolah adalah PTBL, KTDL, TOL, dan PTUL. Urutan penyajian materi pada SMAN 4 Palangka Raya adalah PTBL, KTDL, PTUL, dan TOL. (2) Urutan penyajian materi dalam pokok bahasan sifat koligatif larutan pada siswa kelas XII-IPA SMA Negeri Palangka Raya tahun ajaran 2018/2019 berdasarkan jenis kelamin pada siswa laki-laki urutan penyajian materi yaitu PTBL, KTDL, TOL, dan PTUL. Urutan penyajian materi pada siswa perempuan yaitu PTBL, KTDL, PTUL, dan TOL. (3) Urutan penyajian silabus adalah PTUL, KTDL, PTBL, dan TOL. Urutan penyajian materi dalam pokok bahasan sifat koligatif larutan pada siswa kelas XII-IPA SMA Negeri Palangka Raya tahun ajaran 2018/2019 berdasarkan nilai rata-rata tes (mean), yaitu KTDL, PTBL, TOL, dan PTUL.

\section{DAFTAR PUSTAKA}

Aida, dkk. (2012). Analisis Kesulitan Pemahaman Siswa pada Materi Sifat Koligatif Larutan dengan Menggunakan Three-Tier Multiple Choice Diagnostic Test” di Kelas XII IPA 2 SMA Negeri 5 Banda Aceh. Banda Aceh: Prodi Kimia FKIP Universitas Syiah Kuala.

Alina. (2018). Korelasi Antar Topik dalam Pokok Bahasan Hukum Dasar Kimia

Pada Siswa Kelas X-IPA SMA Negeri Palangka Raya Tahun Ajaran

2017/2018. Skripsi. Palangka Raya: Prodi Pendidikan Kimia Jurusan Pendidikan MIPA UPR.

Arifin, Z. (2012). Evaluasi Pembelajaran. Jakarta: Direktorat Jenderal Pendidikan

Islam Kementerian Agama RI.

Bahri. (2008). Konsep dan Definisi Konseptual. Jakarta: PT. Raja Grafindo

Persada.

Chang, R. (2010). Chemistry 10th Edition. New York: The McGraw-Hill

Companies, Inc.

Dahar, R. W. (2010). Teori-teori Belajar dan Pembelajaran. Jakarta: Erlangga.

Depdiknas. (2002). Pedoman Pendayagunaan Peralatan Laboratorium. Jakarta: BSNP.

Dini. (2014). Analisis Konsepsi Mahasiswa Melalui Instrumen Penilaian Three-

Tier Multiple Choice Berorientasi Taksonomi Bloom Revisi pada Konsep

Sifat Koligatif Larutan. Skripsi. Bandung: Program Studi Pendidikan

Kimia UIN Sunan Gunung Djati.

Direktorat Pembinaan SMA. (2010). Juknis Analisis Butir Soal Di SMA. Hal 129. 
Hamzah, M. A. (2014). Evaluasi Pembelajaran Matematika. Jakarta: RajaGrafindo Persada.

Irfan, A. (2000). Ilmu Kimia. Erlangga: Jakarta.

Jonedi. (2016). Analisis Susunan Materi Pelajaran Kimia Kurikulum 2013 berdasarkan Korelasi dan Tingkat Kesukaran Kelas XI IPA Semester Ganjil pada SMA Negeri Palangka Raya Tahun Ajaran 2014/2015. Skripsi. Palangka Raya: Prodi Pendidikan Kimia Jurusan Pendidikan MIPA UPR.

Kean, E. dan Middlecamp, C. (1985). A Survival Manual for General Chemistry (Panduan Belajar Kimia Dasar). Penerjemah: A. Hadyana Pudjaatmaka. Jakarta: Gramedia.

Muhidin, M. A. (2007). Analisis Korelasi, Regresi, dan Jalur dalam Penelitian (Dilengkapi Program Program SPSS). Bandung: CV. Pustaka Setia.

Siregar, S. (2013). Metode Penelitian Kuantitatif : Dilengkapi Perbandingan

Perhitungan Manual \& SPSS Edisi Pertama. Jakarta : Kencana Prenada Media Group.

Sidauruk, S. (2005). Miskonsepsi Stoikiometri pada Siswa SMA. Disertasi. Yogyakarta: Program Pascasarjana Universitas Negeri Yogyakarta. Sudarmo, U. (2013). KIMIA 3 untuk SMA/MA Kelas XII. Jakarta: Erlangga Sukma, dkk. (2014). Analisis Kesalahan Konsep Sifat Koligatif Larutan Pada Mahasiswa Kimia Universitas Negeri Malang Dan Eliminasinya Menggunakan Media Visualisasi Statik. Malang: Universitas Negeri Malang.

Rachman, T. (2018).Korelasi Antar Topik Dalam Pokok Bahasan Ikatan Kimia pada Siswa Kelas X-IPA SMA Negeri Di Kabupaten Katingan Tahun Ajaran 2017/2018. Skripsi. Palangka Raya: Prodi Pendidikan Kimia Jurusan Pendidikan MIPA UPR. 